\title{
IMPACT OF SALES PROMOTION, ADVERTISING AND DIRECT MARKETING ON SALE OF COSMETIC PRODUCTS
}

\author{
Zawar Khan ${ }^{1}$
}

\begin{abstract}
Retail markets have been one of the most rapid-growing markets in the world for the last decade; to stay competitive, retailers use effective sales promotions tools and that become a vital technique for marketers to stimulate consumer buying behavior towards purchasing any product. This study aims to determine the impact of the most used tools of sales promotion in the retail sector such as coupons, sample, price discount and buy one get one free on consumer buying behavior from two aspects: brand switching and customer loyalty. This study based on a literature review, conceptual framework and hypothesis which open the door for future researchers to expand more in this field.

Keywords: Sales Promotions Tools, Consumer Buying Behavior, Free Sample, Price Reduction, Purchase Decisions, Coupon.
\end{abstract}

\section{INTRODUCTION}

In today's competitive world, the existence and development of organizations and companies depend on proper marketing and selling of products and services. Today's marketing is not based on producing facilities but rather on providing appropriate information channels for the consumers. "Successful companies must identify proper ways of persuading customers in order to preserve their situation in market share and competitiveness(Hosseini, and Navaie, 2011). In this research, various variables that affect sale are identified and also its impact on sale is studied. It is very important to understand your customer preferences towards your product so that it will create a significant impact on the sale. Increasing sales is basically a core objective of any organization to

\footnotetext{
${ }^{1}$ IoBM, Zawarkhan0078@gmail.com
} 
achieve. Most of the organization move out of track to achieve the objective. This research is also an addition to the factors that will eventually enhance the sales of the related organizations.

The persistent problem that organizations face today is to deal with the rapidly changing market dynamics, but the interesting fact is that the share of domestic manufacturers is declining along with the decrease in their sales. A review of the literature shows that no investigations have been done on the subject of the mentioned market and proper ways of persuading consumers. This study thus attempts to answer the question:

At what level the Sales promotion, Advertising and Direct marketing can facilitate increasing the Sale?

The objective of the study is to find out up to what extent Sales of an organization are related to and influenced by marketing activities including sales promotion, advertising, and direct marketing strategies. Though it is noticeable that these predecessors would have a direct positive relation with sales, the objective is to experimentally test their dependency on each other.

\section{SIGNIFICANCE OF THE STUDY}

The significance of research on Sale is supreme because it will help to dictate what factors promote the increased sale that will in due course lead to the company's success.

\section{LITERATURE REVIEW}

In all marketing processes, marketers try to infuse quality in the minds of customers in order to provide values around which repurchase, and sales promotion shape up. Indeed, marketing seeks a proper way of satisfying customers' demand at end of which successful companies get distinguished from the unsuccessful ones. Considering the use of cosmetics products by a vase range of families increases competitiveness unconsciously. Besides, competition in the cosmetics product industry involves especial condition due to the short life cycle.(Hosseini, \& Navaie, 2011). Sales promotion has direct impact on the consumers buying behavior, which is an action focuspromoting occasion. The word sales promotion denotes to numerous types of selling incentives 
and procedures which aim to yield the urgent sales effects. Three types of methods can be used by marketers to increase sales, the first is to strengthen used to target consumers called consumer sales promotion. Sales promotion is directed at customers, distribution channel or sales staff called enhanced retail. Sales promotion aimed at retailers, wholesalers and sales promotion called the trade.

Typical tools include of free samples, price reduction, buy one get one free and the coupons, and also sales promotion, and so on. But in this study, we will discuss the impact of a free sample, price reduction, buy one get one free and the coupons on consumer purchasing behavior and sales promotion. Buying behavior and consumers are demanding generally not the end to meet the wants and pleasure of getting something new or superior to each human being his own behavior and attitudes and thinking while choosing the products, services and purchasing decisions. Therefore, there is a large body of literature that studied the consumer to buy. Alpha Shopping integrates a societal experience outside the house and there is a relationship between time consumed and with social companions. The surrounding material is circumstantial factor that consumers buy the effects of behavior. These promotional techniques affect the buying behavior of consumers during races. Price reduction is well-known tool for offering a good reduction in purchase price, which is openly declared on the product or point of purchase display. Sampling is the method of giving less numbers of products to the customers without any cost, so that they can checked it and buying the product in near future. Previous research has shown that these factors have a great relationship with the buying behavior of consumers. The effects of these tools vary from one country to another. Our study so that they can generate different results from the previous study.

\section{THEORETICAL FRAMEWORK}




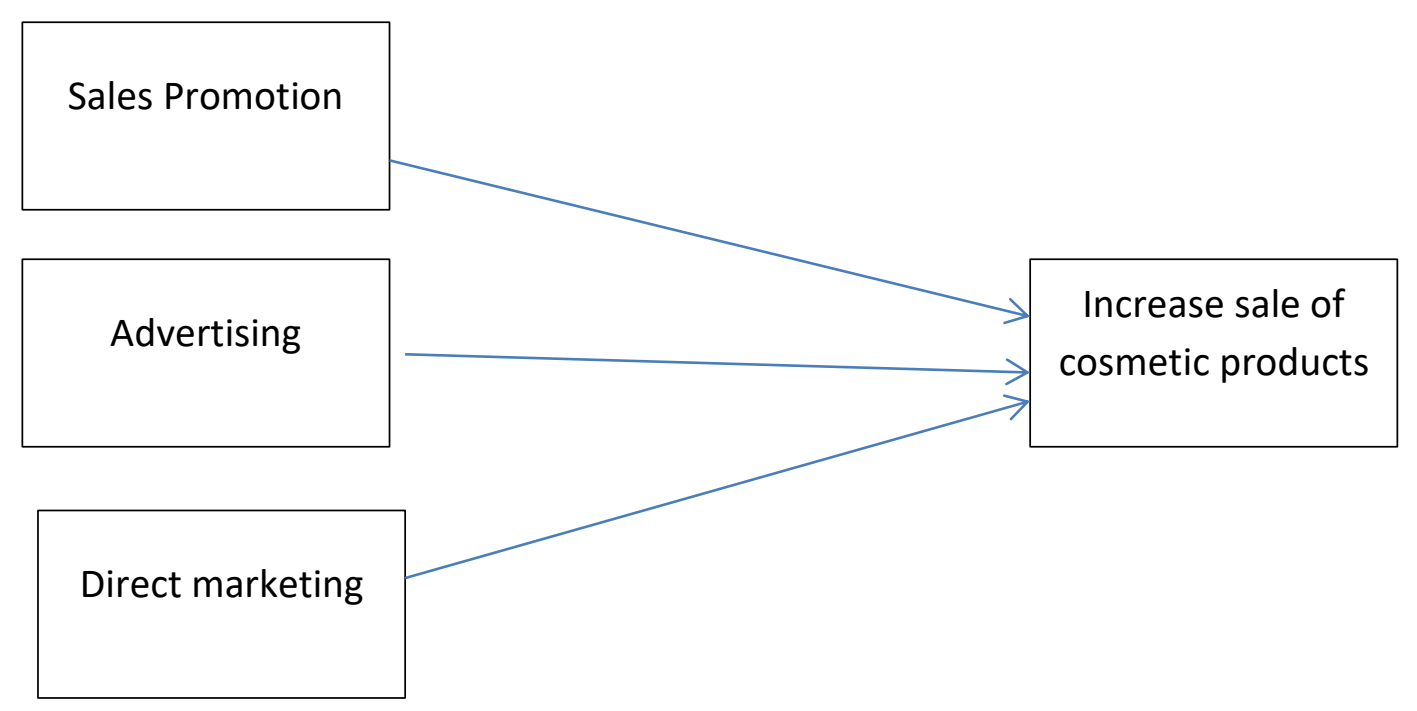

\begin{tabular}{|l|l|}
\hline Sales Promotion--------------Increase the sale of cosmetic Product & $\begin{array}{l}\text { (Hosseini, and Navaie, } \\
2011)\end{array}$ \\
\hline Advertising --------------- Increase the sale of cosmetic Product & $\begin{array}{l}\text { (Hosseini, and Navaie, } \\
2011)\end{array}$ \\
\hline Direct Marketing ----------- Increase the sale of cosmetic Product & $\begin{array}{l}\text { (Hosseini, and Navaie, } \\
2011)\end{array}$ \\
\hline
\end{tabular}

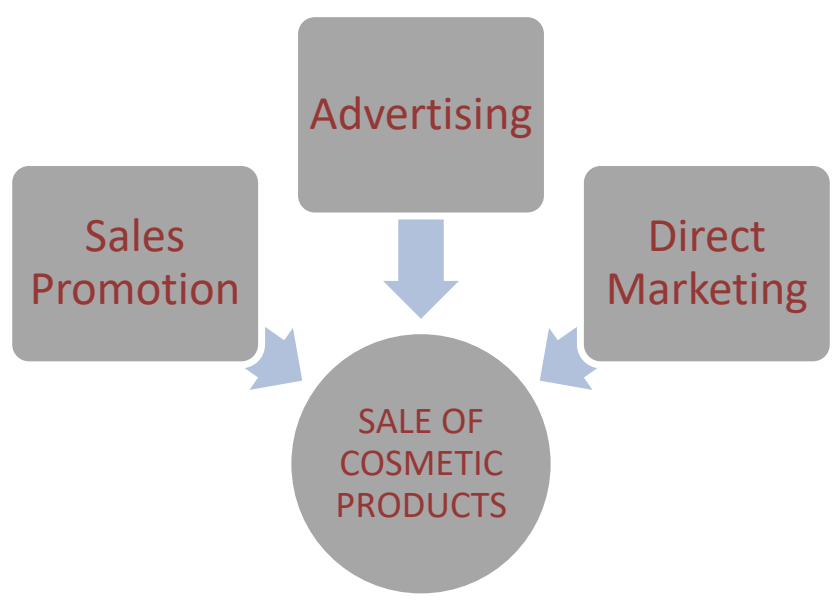

The above conceptual framework explains that our dependent variable is the Sale of cosmetic products, whereas the independent variables that affect are Sales Promotion, Advertising and Direct Marketing. While testing the relationship organizational Sale Promotion and Increase in Sale is of the most importance, as such relationships affect the productivity of the organization. 
Advertising is one of the tools that stimulate and create new opportunities to attract the potential customer and Direct Marketing give the impression that how many customers involve in taking any purchase decision.

\section{RESEARCH HYPOTHESIS}

H1: Sales Promotional has a significant positive impact on Sale.

H2: Advertising has a significant positive impact on Sale.

H3: Direct Marketing has a significant positive impact on Sale.

Hypotheses Testing Model
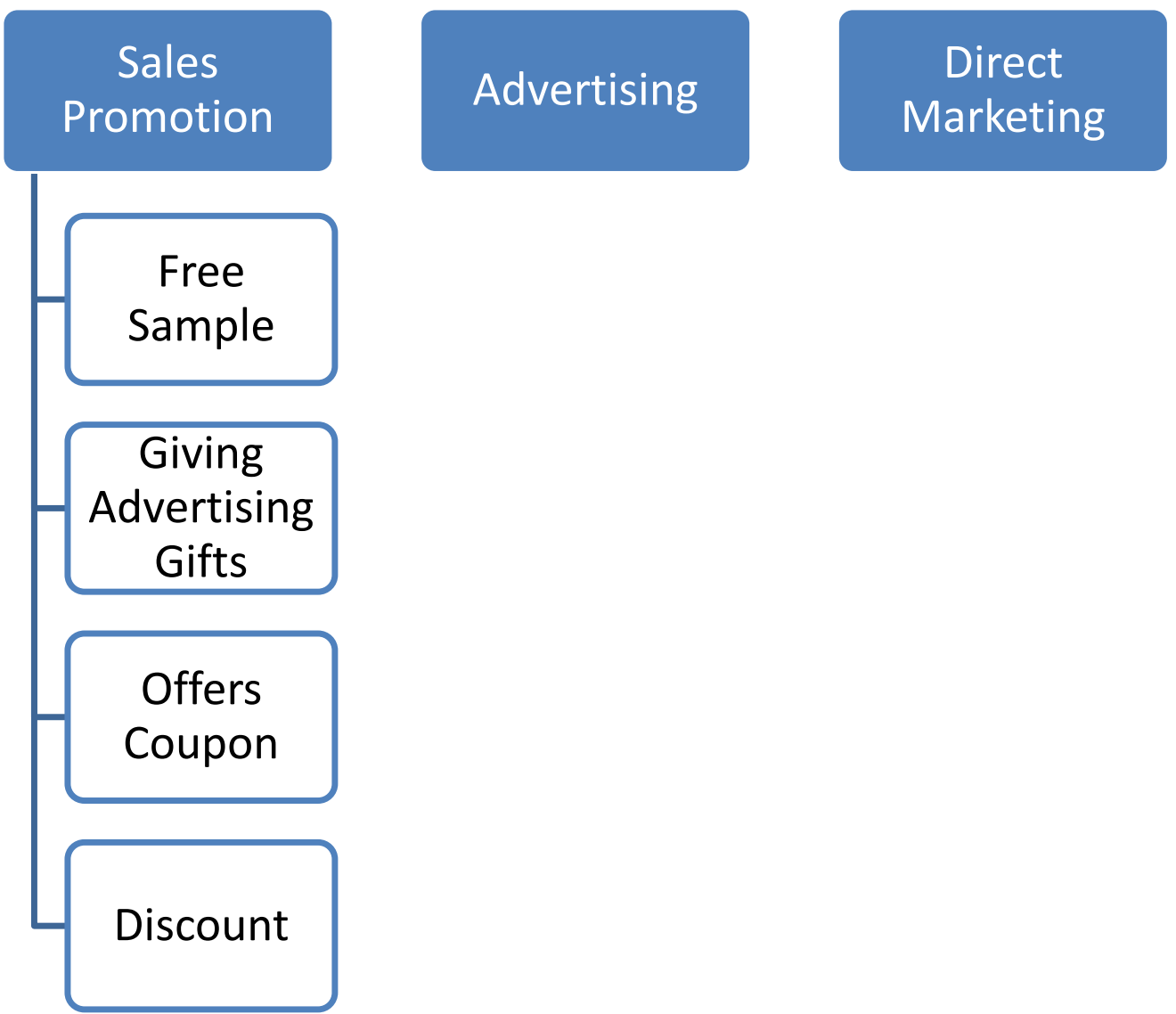

\section{Marketing}




\begin{tabular}{|c|c|c|}
\hline Free sample & $\begin{array}{l}\text { Q1 If a brand offers a free sample that could be a reason } \\
\text { for me to buy it. } \\
\text { Q2 When I buy a brand that offers free sample, I feel I } \\
\text { am getting a good buy. } \\
\text { Q3 I have favorite brands, but most of the time I buy a } \\
\text { brand that offers a free sample. } \\
\text { Q4 One should try to buy a brand that offers a free } \\
\text { sample. } \\
\text { Q5 Compared to most people, I am more likely to buy } \\
\text { brands that offer free sample. }\end{array}$ & $\begin{array}{l}\text { Awareness and } \\
\text { usage of promotion } \\
\text { tool (Ndubisi, n.d.) }\end{array}$ \\
\hline $\begin{array}{c}\text { Advertising } \\
\text { Gift }\end{array}$ & $\begin{array}{l}\text { Q1 Who in your company normally makes decisions } \\
\text { regarding corporate gifts and incentives? } \\
\text { Q2 Who is the recipients of the gifts and incentives? } \\
\text { Q3 Do you prefer "customized" or "off-the-shelf" gifts? } \\
\text { Q4 How important is it that gifts features your } \\
\text { company's logo /name? } \\
\text { Q5 What, if any, are the key periods in the year when } \\
\text { you decide the need for gifts? } \\
\text { Q6 On which occasions do you use gifts and incentives? } \\
\text { Q7 Where does the expenditure of gifts come from? } \\
\text { Q8 Do you feel that corporate gifts and incentives } \\
\text { achieve their purpose/objective? }\end{array}$ & (Fan \& Ln, 2006) \\
\hline $\begin{array}{l}\text { Offering } \\
\text { Coupon }\end{array}$ & $\begin{array}{l}\text { Q1 If a brand offers coupon that could be a reason for me } \\
\text { to buy it. } \\
\text { Q2 When I buy a brand that offer coupon I feel I am } \\
\text { getting a good buy. } \\
\text { Q3 I have favorite brands, but most of the time I buy a } \\
\text { brand that offers coupon. } \\
\text { Q4 One should try to buy a brand that offers coupon. } \\
\text { Q5 Compared to most people, I am more likely to buy } \\
\text { brands that offer coupon. }\end{array}$ & $\begin{array}{c}\text { Awareness and } \\
\text { usage of promotion } \\
\text { tool } \\
\text { (Ndubisi, n.d.) }\end{array}$ \\
\hline Discount & $\begin{array}{l}\text { Q1 I Like getting a personal discount from the retailer on } \\
\text { my purchases rather than an advertised discounts } \\
\text { Q2 I feel the retailers who give me a discount get a larger } \\
\text { discount from the wholesaler } \\
\text { Q3 Discounts and rebates are more often given by brands } \\
\text { which are being newly launched or cheap brands } \\
\text { Q4 When a retailer gives me a discount I am conscious of } \\
\text { the fact that the product might be defective or nearing } \\
\text { expiry date }\end{array}$ & (Banerjee, 1989) \\
\hline Advertising & $\begin{array}{l}\text { Q1 Advertising helps me keep up-to date about product } \\
\text { and services that I need or would like to have. } \\
\text { Q2 too many products do not perform well as well as the } \\
\text { ads claim. } \\
\text { Q3 Advertising is more manipulative than it is } \\
\text { informative. }\end{array}$ & Mehta (2000) \\
\hline
\end{tabular}




\begin{tabular}{|c|l|c|}
\hline & Q4 I like to look at advertising. & \\
& Q5 On average, brands that are advertised are better in \\
quality than brands that are not advertised. & \\
Q6 Much of advertising is way to annoying. & \\
Marketing & Q1 During the past year, they or a member of their & (Culnan, 1995; \\
& household had purchased something from a mailing? & Milne, \& Rohm, \\
& Q2 When you receive mail offers at your residence to \\
sell you products or services, how do you regard these? & 2000). \\
& $\begin{array}{l}\text { 1) Primarily as an invasion of privacy. } \\
\text { 2) Primarily as a nuisance. }\end{array}$ & \\
3) You rarely use the offers, but do not see them as a & \\
4) Primarily as a useful opportunity. & Q3 How concerned are you about threats to your \\
privacy? & Q4 Have you ever personally been the victim of an \\
improper invasion of privacy? & \\
\hline
\end{tabular}

\section{RESEARCH METHODOLOGY}

The basic aim of the study is to gather an in-depth understanding and to test the relationship that how different factors are affecting Sale. Furthermore, within quantitative regulation, it's confirmatory research (Hypothesis Testing) in which previous theories regarding Sale and factors affecting were considered to confirm the relationship between them.

Our research objective is explanatory in nature, as the subject variable has already been investigated by some researchers. So, this study is going to be an addition to the already existing research on the sale of cosmetic Products. Similarly, the scope of the research is basic. The factors affecting Sale are generalized and are not restricted to a particular organization and is helpful for other industry as well.

\section{Research Technique}

This study is intended to identify the effect of Sale Promotion, Advertising and Direct Marketing on Sale. First, these variables are found by in-depth literature review. To measure these variables, a questionnaire incorporates close-ended questions based on the Likert scale are assembled. The readings will then be tested by applicable test in SPSS to find the relationship. This would be followed by the analysis which would help in enhancing the Sale of the cosmetic products. 
As this study basis on the relationship between independent variables (Sale Promotion, Advertising and Direct Marketing) and dependent variable (Sale of cosmetic products), as this study investigation is Correlational. By which it would find that which of the 3 following independent variables has a possible effect and relationship with Sale of cosmetic Products.

\section{Population and Sample}

Due to the dispersion of cosmetic product consumers, the population in this research consists of females from Karachi who use cosmetic products in their routine. Under the study for the collection of data on the following considered variables. However, the sampling unit chosen for the research is of Female of Karachi fall in the age group of 18-40 years. Because they are familiar with the cosmetics and interest in it. They can also be a decision-maker and influencer as well.

\section{Sampling Technique}

For the current study, the individuals who are most easily available are asked to participate in the study keeping in mind that they belong to the sampling unit defined. So therefore the Convenience Sampling technique is chosen. As this is the easy way for data gathering. On the other hand, it may also do not represent the true result of them and there might not be any generalizability in the study. Thus, the sample size for the study is decided to be 384 .

\section{Instrumentation}

\section{Sales Promotion}

Sales promotion is a short term strategy to derive demand and also and especial marketing offer which provides more profit than what consumers receive from the sale position of a product and also has a sharper influence on sales (Banerjee, 1989). This tool has the ability to attract and keep loyal customers and is excellent what to persuade them to build a viable link with the organization and involves all motifs applied by the producer to persuade trade with members of a channel (Ndubisi, \& Moi , 2006; Ndubisi, n.d.).

\section{Free Sample}


During the last ten years, the significance of free sample as tools of promotion in the field of cosmetics has been on the rise. According to the investigation done by Denly a marketing company, $75 \%$ of the companies use free samples to improve their products, whereas $52 \%$ of the companies don't advertise their new products. Although representing this method is a powerful promotion tool, it requires high costs for the organizations (Ben et al., 2009). A five-point Likert scale, ranging from one (strongly disagree) to five (strongly agree) was used for the construct's dimensions ( Ndubisi, \& Moi , 2006; Ndubisi, n.d.).

\section{Corporate Gifts}

Proper gifts are one of the best ways to transfer the message that communication is important. Oral communications are soon forgotten but gifts with the company's mark on it act as a reminder and attract the customers (Fan \& Ln, 2006). The questionnaire contained 8 questions with a mixture of multiple choices and open-end questions (Fan \& Ln, 2006).

\section{Offer Coupon}

Coupon has a direct influence on the increase of the sale through which consumer's tendency toward the product increases (Gloria et al., 2009). This is one of the oldest and yet most common tools of promotion which has been applied since 1895 and during recent years has become a known term for producers and retailers as a tool to encourage sale has been on the rise and accepted to the consumers more than any other promotion method (Banerjee, 2009; Banerjee, 1989). A five-point Likert scale, ranging from one (strongly disagree) to five (strongly agree) was used for the construct's dimensions (Gilbert, \& Jackaria, 2002; Ndubisi, n.d.).

\section{Discount}

Price promotion plays a role of increasing importance in current markets. Special emphasis on price promotions is pronounced in the grocery industry, where retailers frequently use temporary price discounts to lure customers into stores and boost sales. Retailers spend an increasing amount of money on temporary price reductions and the management of this promotional activity can be improved through careful measurement of its effects. With superior knowledge of these effects, retailers can improve their decisions about temporary price reduction (Martínez-Ruiz, MolláDescals, Gómez-Borja, \& Rojo-Álvarez, 2006.). A five-point Likert scale, ranging from one 
(strongly disagree) to five (strongly agree) was used for the construct's dimensions (Banerjee, 1989).

\section{Advertising}

Advertising is a "marketing tactic involving paying for space to promote a product, service, or cause. The actual promotional messages are called advertisements, or ads for short. The goal of advertising is to reach people most likely to be willing to pay for a company's products or services and entice them to buy. A five-point Likert scale, ranging from one (strongly disagree) to five (strongly agree) was used for the construct's dimensions (Mehta, 2000).

\section{Direct Marketing}

Direct marketing is a promotional method that involves presenting information about your company, product, or service to your target customer without the use of an advertising middleman. It is a targeted form of marketing that presents information of potential interest to a consumer that has been determined to be a likely buyer. The items of direct marketing will be measured by three items on a four-point ascending scale ranging from strongly disagree to strongly agree.

\section{DATA ANALYSES}

\section{Reliability Test}

It is used to test the consistency and stability that how well the items measuring a concept hang together as a set. Cronbach's Alpha is the reliability coefficient that indicates how well the items in the set are positively correlated to one another. The closer Cronbach Alpha for this research is to 1 , the higher the consistency reliability. Reliabilities less than 0.60 are considered poor those in the 0.70 range are acceptable and those over 0.80 good.

\begin{tabular}{|c|c|c|}
\hline Scale & Items & Cronbach Alpha \\
\hline Sales Promotion & 22 & 0.746 \\
Advertising & 5 & 0.790 \\
Direct Marketing & 4 & 0.756 \\
\hline
\end{tabular}

\section{Validity Test}


Descriptive statistics such as maximum, Minimum, Mean, standard deviation and variance were obtained for the multi-item interval- scale independent and dependent variable.

\begin{tabular}{|l|l|l|l|l|l|l|}
\hline & $\mathbf{N}$ & Minimum & Maximum & Mean & $\begin{array}{l}\text { Std } \\
\text { Deviation }\end{array}$ & Variance \\
\hline Sales & 174 & 1.00 & 4.00 & 2.19 & 0.97 & 0.94 \\
Promotion & 173 & 1.00 & 5.00 & 3.24 & 1.32 & 1.74 \\
Advertising & 171 & 1.00 & 5.00 & 2.32 & 0.97 & 0.94 \\
Direct \\
Marketing
\end{tabular}

\section{Data Analysis Plan}

The data analysis of the collected data for the three developed construct and hypothesis is measured through the following three statistical techniques.

\begin{tabular}{|c|c|}
\hline Constructs/ Hypothesis & Statistical Techniques \\
\hline $\begin{array}{l}\text { Ho: Sales Promotion has no significant } \\
\text { Positive impact on Sale. } \\
\text { H1: Sales Promotional significant positive } \\
\text { impact on the Sale }\end{array}$ & $\begin{array}{l}\text { The following construct is also qualitative } \\
\text { Multichotomous and the technique used is One } \\
\text { Way Anova. }\end{array}$ \\
\hline $\begin{array}{l}\text { Ho: Advertising has no significant positive } \\
\text { impact on sale } \\
\text { H1: Advertising has significant positive } \\
\text { impact on the Sale. }\end{array}$ & $\begin{array}{l}\text { The following construct is also qualitative } \\
\text { Multichotomous and the technique used is One } \\
\text { Way Anova. }\end{array}$ \\
\hline $\begin{array}{l}\text { Ho: Direct Marketing has no significant } \\
\text { positive impact on sale } \\
\text { H1: Direct Marketing has significant positive } \\
\text { impact on the Sale. }\end{array}$ & $\begin{array}{l}\text { The following construct is also qualitative } \\
\text { Multichotomous and the technique used is One } \\
\text { Way Anova. }\end{array}$ \\
\hline
\end{tabular}

Hypothesis Testing

\begin{tabular}{|c|c|}
\hline Variable & Sig Value \\
\hline Sales Promotion & 0.05 \\
\hline Advertising & 0.04 \\
\hline Direct Marketing & 0.04 \\
\hline
\end{tabular}

\section{DISCUSSION}




\section{Sales Promotion}

According to the results of the study, Sales Promotion has a significant relationship with the Increase sale of cosmetic products with a Sig value of 0.05. That means the Sales Promotion contributes $5 \%$ to increase the sale of the cosmetic product of the existing study. Results of the present study do validate the $\mathrm{H} 1$.

\section{Advertising}

One way ANOVA Analysis of the increased sale of cosmetic products model shows that there is a significant positive relationship between Advertising and an Increase in sale with a Sig value of 0.04. The results suggest that Advertising contribute $4 \%$ to Increase in the sale. The results of the study support $\mathrm{H} 2$.

\section{Direct Marketing}

According to the outcomes of the study, Direct Marketing has a significant positive relationship with the Increase in the sale. The One-Way ANOVA outcomes of Direct Marketing with an Increase in the sale are significant with a sig value of 0.04 . That means direct marketing has a $4 \%$ Increase in the sale. Results of the present study do validate the H3.

\section{CONCLUSION}

Sale promotion can be a powerful tool to induce consumers and guide into the increase of sales and profits and make most of those who don't have the experience of the product try it at least once. Testing of research hypotheses (One-way ANOVA) showed that sale promotion, advertising and direct marketing are dominant factors in the increase of sales in cosmetic products since they improve costumers' awareness and induce them to try the product. Moreover, tools of promotion mix and elements of every tool influencing the increase of the sale were rated which shows sales promotion stands above all other components followed by sales advertising and direct marketing. Among sales promotion tools, giving free sample stands above all elements followed by giving advertising gifts, coupons and discount. Among advertising media, magazines are the most important to people followed by TV, radio.

\section{RECOMMENDATIONS}


Along with research results, some suggestions are presented below to increase sales of cosmetic products to introduce cosmetic product using free small sample packages for consumers to try the product in a new useful way. Giving advertising gifts with the company's logo on it acts as a drive and reminder of the hair cosmetic product. Providing experts with adequate information on the product in order to introduce products and the motivation of the customers is very important. Situational and seasonal discounts are useful ways to provide motivation to increase sales. Marketers play an important role in introducing the product and provide a positive conception of the product. Since there is a positive relationship between promotion mix components in increasing sales, we can conclude that the outcome of promotion mix components are stronger than every single component, so a simultaneous application of all methods can bring additional effect.

\section{FUTURE RESEARCH DIRECTIONS}

Studying the role and the significance of the marketing mix components (product, price and location) in the increase of sales of cosmetic products. Studying the role and significance of marketing mix in the increase of sale of other products. Studying obstacles and difficulties in advertising beauty products and presenting approaches to overcome this limitation. Presenting approaches to introduce beauty products to the market in an effective way. 


\section{REFERENCES}

Banerjee, S. (2009). Effect of product category on promotional choice: comparative study of discounts and freebies. Management Research News.

Banerjee, S. (1989). Effect of product category on promotional choice : comparative study of discounts and freebies. https://doi.org/10.1108/01409170910927587

Ben, I., Francis, A., \& Amor, I. Ben. (2009). Influences on free samples usage within the luxury cosmetic market. https://doi.org/10.1108/17505930910945741

Culnan, M. J. (1995). Consumer awareness of name removal procedures: Implications for direct marketing. Journal of direct marketing, 9(2), 10-19.

Fan, Y., \& Ln, L. (2006). Corporate Gifts As A Marketing Tool: A Survey In The UK Airline Industry.

Gilbert, D. C., \& Jackaria, N. (2002). The efficacy of sales promotions in UK supermarkets: a consumer view. International Journal of Retail \& Distribution Management.

Gloria, J., Suzanne, M., Nasco, A., \& Meng, J. G. (2009). Cross-cultural equivalence of price perceptions across American, Chinese, and Japanese consumers. https://doi.org/10.1108/10610420910998235

Hosseini, M. H., \& Navaie, M. S. (2011). Analyzing The Influence of Promotion Mix On Increase of Sale in Cosmetics and Beauty Products. Asian Journal of Business and Management Sciences, 1(4), 99-113.

Martínez-Ruiz, M. P., Mollá-Descals, A., Gómez-Borja, M. A., \& Rojo-Álvarez, J. L. (2006). Evaluating temporary retail price discounts using semiparametric regression. Journal of Product \& Brand Management.

Mehta, A. (2000). Advertising attitudes and advertising effectiveness. Journal of advertising research, 40(3), 67-72.

Milne, G. R., \& Rohm, A. J. (2000). Consumer privacy and name removal across direct marketing channels: Exploring opt-in and opt-out alternatives. Journal of Public Policy \& 
Marketing, 19(2), 238-249.

Ndubisi, N. O., \& Moi, C. T. (2006). Awareness and usage of promotional tools by Malaysian consumers: the case of low involvement products. Management Research News.

Ndubisi, N. O. (n.d.). Awareness and usage of promotional tools by Malaysian consumers : the case of low involvement products. https://doi.org/10.1108/01409170610645420 